\title{
A Physical Dictionary (1657): The First English Medical Dictionary
}

\author{
Jukka Tyrkkö \\ Research Unit for Variation, Contacts, and Change in English \\ University of Helsinki
}

\section{Introduction ${ }^{1}$}

Published in 1657, A Physical Dictionary was the first English dictionary to focus on medical terminology. Surprisingly, given the amount of interest all matters medical hold for historians, the dictionary has been practically ignored in both historical accounts of English lexicography and the history of medicine. In its stead, another Physical Dictionary, the 1684 English translation of Stephen Blankaart's Lexicon medicum Graeco-Latinum (1679), has often been identified as the first. ${ }^{2}$ Several reasons can be given for this. The latter, unlike the first, was associated with a well-known medical authority and was admittedly of a wider lexical scope, but perhaps the most important reason why the first Physical Dictionary came to be forgotten is its historical context. The two dictionaries, although appearing less than thirty years apart, are separated by both the Great Plague and the Fire of London, events which temporarily destroyed almost the entire printing industry, disrupting the lives of all those involved in producing the first medical dictionary. This paper follows a train of thought that emphasises the need to focus attention on the wider production circumstances of early dictionaries as much as on their contents in determining how they came to be.

The main objective of this paper is to present a lexicographical description of A Physical Dictionary with a particular view to demonstrating how it was a substantial medical reference work at a time when none existed in the vernacular, as well as showing its particular propensity for apothecary terminology. Starting with a lexicographical description of the headwords and their explanations, the paper assesses the lexicographical work of the dictionary's unknown author, particularly from the perspective of ascertaining whether the compilation of the dictionary can reasonably be attributed to a single author and what headwords and their explanations might tell us about the lexicographer. This examination leads to the second part of the paper, in which I discuss the relationship of the Physical Dictionary with earlier and contemporary medical lexicons. In previous scholarship, Alston (2004) and Schäfer (1989) have identified the several sources of the Physical Dictionary. I expand the list, and discuss the claim posted on the Antiquarian Booksellers Association of America website refuting Alston's observation that the Physical Dictionary was derived from the glossary published with another medical title, the Practice of Physick (1655). ${ }^{3}$ Finally, building on the observation that the dictionaries and glossaries

\footnotetext{
1 This paper was written with funding by the Research Unit for Variation, Contacts, and Change in English at the University of Helsinki, funded by the Academy of Finland. I am grateful for a travel grant from the Department of English, which made a visit to the British Library and the Wellcome Trust Library possible. I am particularly grateful to the anonymous reviewer for many valuable comments.

2 The two dictionaries have been confused with each other by many scholars. The Oxford English Dictionary, for example, cites the title Physical Dictionary 57 times, 27 of which are first datings. Citations to Garfield's Physical Dictionary, labeled "1657 Phys. Dict", go from the beginning of the alphabet to "lutation" — while those labeled "Blancard's Phys. Dict." begin from "pyosis". Not a single citation to Garfield's dictionary is found after "lutation", not a single citation to Blankaart's before "pyosis." It seems likely that the 1657 Physical Dictionary was read for the beginning of the alphabet and the 1684 one for the end.

3 See entry on A Physical Dictionary at $<\mathrm{http} / / \mathrm{http}: / /$ search.abaa.org/>.. The same entry has also appeared on the Abebooks website at $<$ http://www.abebooks.com $>$.
} 
used as sources appear to have been printed contemporaneously in Cornhill, I discuss how researching networks of book production may in some cases help us understand how the lexicographical heritage functioned.

\section{Context}

To fully appreciate the historical significance of the Physical Dictionary, we will do well to bear in mind that by the middle of the seventeenth century only four general monolingual English dictionaries had been published: Cawdrey's, Bullokar's, Cockeram's, and Blount's. Although special field dictionaries in general predate general purpose ones (see Osselton 1998), none were available on medicine beyond brief glossaries occasionally included with medical treatises. ${ }^{4}$ Medical terminology had been well represented in Latin dictionaries since the early sixteenth century (see McConchie 1997: 98-101), but they were of little use to the increasing numbers of monoglot readers. As printing made medical texts increasingly available to literate laymen, the need for a resource giving English explanations of medical terms became more and more apparent.

In one of the few modern references to A Physical Dictionary, Blank (2006: 235) notes that

these texts [works like A Physical Dictionary] must be acknowledged alongside Cawdrey's or Bullokar's contributions to vernacular lexicography; they, too, are English-English dictionaries, defining the 'dialects' of the disciplines.

That the 'dialect' of medicine was largely derived from Latin is not only significant from the purely linguistic point of view. The issue of language choice was much more politically charged in medicine than in many other fields, with the controversy fundamentally tied to both authority and commercial interests, and at least peripherally to religion. According to Furdell "writing about medicine at all, let alone publishing recipes and remedies in the vernacular, undermined the secretive traditions of the orthodox medical community" (2002: 83). The theory and tradition of university medicine was Latinate, and it was the use of Latin that helped retain the authority of the classical Greek authorities whose validity came increasingly into question during the seventeenth century (see Furdell 2002: 8182). Latin - and significantly for lexicography, Latinate terminology — effectively continued to limit the discussion of scientific issues to the relatively few university trained physicians. It is therefore not surprising that, despite rapidly advancing vernacularization, Latin continued to have its advocates among the medicos, particularly those of the Royal College of Physicians, which required members to master Latin, and tried to impose limits on the printing of medical works in English. ${ }^{5}$ The issue was not only one of science. The financial interests of the learned medicos were very much at stake, and thus, predictably, their chief rivals, the empirics, ${ }^{6}$ saw language as a significant part of the controversy. The empirics not only questioned the scholastic tradition and embraced new theories based on first-hand observation and experiment, but also argued that medical works should be printed in the vernacular. The fact that many of the empirics were also puritans cannot be discounted either (cf. Webster 1975), as an analogy can be seen between the empirics demand for medical vernacularization and the puritans belief in vernacularization of religious writing (see Furdell 2002: 80-81). Although recent scholarship has tended to downplay the connection between printers' and stationers' political allegiances and what they printed (see, e.g., Wear 1996), it seems clear that the Interregnum saw the grip of the College of

\footnotetext{
4 Glossaries had been included with English medical works from the early sixteenth century onwards. Notable ones include those in Giovanni de Vigo's The Most Excellent Workes of Chirurgerye (1543), Robert Recorde's The Urinal of Physic (1547), and Brugis' Marrowe of Physicke (1640). The only widely available special field lexicon of medicine was Castellus' Lexicon Medicum Graeco-Latinum (1598). Published in numerous editions over a period of nearly 200 years, it remained the definitive medical dictionary for over a century; see Schaeder (1994).

5 On financial matters as a driving force in Late Medieval and Renaissance medicine, see French (2003).

${ }^{6}$ The ranks of the empirics included surgeons, barber-surgeons, astro-physicians, iatrochemists, apothecaries, and a whole host of other less well-defined groups of healers and mountebanks (Porter 1992: 96-99). For discussion of empiricism, see Grafton 1992.
} 
Physicians on medical printing weaken, thus enabling more empirical titles to flood the market.

Despite the opposition of the establishment, ${ }^{7}$ medical works were predominantly printed in English by the Interregnum - and not merely for the benefit of the non-professional readership for whom the rapid increase in printing had meant a massive improvement in the availability of texts on health and basic remedies. While members of the literate public seem the most obvious consumers of vernacular medicine, the fact is that most medical practitioners were trained in apprenticeship outside the Latinate schools (cf. Siraisi 1990 and Porter 1992) and, since the sixteenth century, the ability to read Latin had deteriorated even among the university trained physicians. ${ }^{8}$ By the seventeenth century large sections of the student body at Oxford, Cambridge, and Edinburgh were only marginally competent in Latin; enough to struggle through set texts, but unable to read Latin effortlessly. Most physicians were incapable of producing anything original in that language (McConchie 2002: 272-273) and according to Finkelstein and McCleery (2005: 111), only scientists interested in writing for the international audience continued to use Latin (c.f. Feather 1988, French 2003: 204). Healers of other ranks were worse off still, with the majority knowing only the rudiments of Latin terminology with no access to the full texts.

Against this backdrop, the printing of the Physical Dictionary may be seen at least partly as a product of the upsurge the empirical and puritan movements enjoyed during the Interregnum. Although it is not my intention to enter into the broad and hotly contested debate about the extent to which printers and stationers aligned themselves along religious or ideological lines, it does seem that in the particular case of the Physical Dictionary the happy coincidence of a number of like-minded stationers and printers working close to each other in the Cornhill area at the very least aided the process. Unlike their modern counterparts, early topical dictionaries were compiled by lone lexicographers who as often as not were not specialist in the particular field. Copying and collaboration were thus perhaps even more important than in general lexicography. The study of the origins of the Physical Dictionary may thus also help illuminate more generally the processes of making special field dictionaries.

\section{A glossary and a dictionary}

The Physical Dictionary began life as a glossary commissioned for A Medicinal Dispensatory (1657), ${ }^{9}$ the English translation of the unabashedly empirical Dispensatorium Medicum (1609) by the Parisian physician and apothecary Jean de Renou. ${ }^{10}$ The epistle to the dictionary, signed by a diverse group of fourteen English medicos, makes the empirics' case clear:

[A Physical Dictionary] is intended for such persons as spend their time and employment in studying Physick, and are acquainted with no other than their Mother tongue; yet, many times more readily Cure a Disease, by their observant, diligent, and strict keeping to an approved Medicine, than many others, that trust wholly in their Art;

\footnotetext{
${ }^{7}$ Furdell notes that although the official line of university trained physicians was to oppose medical printing in English, many saw the financial benefits of doing so (2004: 71-73).

${ }^{8}$ Salmon notes that although competent use of Latin had diminished by the early 1600 s, Latin was retained as a "quasi-scientific language" useful for fabricating new terminology (1979: 13; see also Norri 2004).

${ }^{9}$ The glossary was published with four of the five contemporaneous editions. The somewhat more modest edition printed for Fletcher apparently did not come with the glossary. The original French treatise did not come with a glossary either.

${ }^{10}$ On the composition and history of the Medicinal Dispensatory, see Trease (1964: 121-126). Jean De Renou (1568-1608) was a prominent physician and apothecary best remembered for his contributions in the field of distillation and materia medica (Wear 2000: 65). The epistle to the Medicinal Dispensatory states that his endeavor is "to purge the whole Body of Pharmacy from the Errata's of the Ancient Grecians." Such a strongly stated empiricist position was relatively rare in the first half of the seventeenth century. The LEME database lists the Physical Dictionary under Renou, the author of the Medicinal Dispensatory, although it is clear that Renou had nothing to do with either the glossary or the dictionary.
} 
Given the ideational landscape of the time, the significance of such a conspicuous endorsement by empirics should not be underestimated. Read in conjunction with the stationer's preface, the epistle makes it clear that the dictionary was not merely intended as a reference work, but that it also had a broader significance.

Judging by the no less that five high quality, folio sized parallel editions, it seems that the English translation was expected to be a commercial success (cf. Mandelbrote 2003: 38), ${ }^{11}$ particularly among apothecaries (see Wear 2000: 65). The five folio editions were printed by John Streater and James Cottrell ${ }^{12}$ for Francis Tyton, Henry Fletcher, Giles Calvert, George Sawbridge and John Garfield. ${ }^{13}$ The Wellcome Library catalogue mistakenly notes that the Medicinal Dispensatory was entered in the Stationer's Register on August 22, 1656 by James Cottrell (also Cotterell). Although Cottrell did indeed enter a title on that date, it was not the Medicinal Dispensatory, but the Enchiridion Medicum. The Medicinal Dispensatory had already been entered two months earlier, on June 14, by Richard Moone, ${ }^{14}$ a printer of seditious pamphlets and a friend and business associate of Cottrell. It seems likely that Cottrell acquired the right to the Medicinal Dispensatory from Moone and either gave up on the Enchridion altogether or else sold it on. No record exists of the Enchiridion ever being published by either Moone or Cottrell. Interestingly, the entries for both the Enchiridion and the Dispensatory give the apothecary Richard Tomlinson ${ }^{15}$ as translator. An addendum by Tomlinson, appearing on a separate page between the index and Book 1 of the Dispensatory, is dated February 1,1657, confirming that the printing had to have taken place after that date.

The glossary was produced by John Garfield, one of the stationers for whom the Medicinal Dispensatory was printed. It was equipped with its own titlepage, clearly identifying it as a separate work from the rest of the Medicinal Dispensatory, and on February 12, 1657, Garfield entered $A$ Physical Dictionary into the Stationer's Register as a free standing title (Wing P2143). Adjusting for the Old Style calendar pushes the date forward by almost a year in relation to the Medicinal Dispensatory. In addition to making it clear that the glossary was considered Garfield's property, rather than an integral part of the Medicinal Dispensatory, the fact that Garfield thought it worth his while to legally protect his interests also suggests that he believed in the dictionary's commercial potential. ${ }^{16}$

A Physical Dictionary is given in the English Short Title Catalogue (ESTC) as Wing P2143 and P2143A. Both printed in the 1657 for John Garfield, P2143 is listed as a duodecimo printed by "G. Dawson" and P2143A as a folio printed by "G.D". The ESTC lists six copies of the folio edition, and

\footnotetext{
11 No second editions were ever printed, however. Although there are many reasons for this, the interruption to London printing caused by the Great Fire must figure heavily in the equation.

12 The two printers merit more attention than can be afforded here. Streater (also Streator) was an anti-Cromwellian and a noted opponent of print-run limits (Furdell 2002: 45). John Streater's son Joseph was both the printer of Newton's Principles of Natural Philosophy and the first printer to be arrested for printing pornography. John Streater died destitute the year before, having lost his fortune after the Restoration. See Johns (1998). Cotrell (also Cotterell), for his part, was constantly in trouble with the Stationer's Company.

13 The stationers form an interesting mix of characters, worthy of closer examination in their own right. Tyton was appointed printer to the House of Lords in 1660 (see Plomer 1907). Sawbridge was equally popular with the state, and died a wealthy man. Giles Calvert was likewise a printer in good standing and once an official printer to the council of state. Fletcher was a minor bookseller, mostly known as the publisher of Sir John Harrington's works. John Garfield will be dealt with in detail.
}

${ }^{14}$ Moone was frequently remanded to the Gatehouse for printing seditious literature (Plomer 1907). According to Plomer, Moone was in correspondence with Elizabeth Calvert, widow of Giles Calvert, one of the booksellers who sold the Medicinal Dispensatory, and while Giles Calvert was an official printer to the council of state, his widow was frequently imprisoned for publishing books that offended the authorities. On the trials and tribulations of Richard Moone, see House of Commons Journal 7, Tuesday 19th of December, 1654. See also Hessayon (2007).

15 The entry for the Enchiridion shows the name "John" struck off and replaced by "Rich: Tomlinson" as translator. The hand and ink being identical, this is is likely to have been a simple clerical error.

16 Although entering a title into the Stationer's Register was not mandatory, it did offer protection against reprinting. Because a fee was involved, only titles with real commercial potential were usually deemed worth protecting. Medical titles were among some of the most frequently registered. See Furdell (2002: 40-41) and Shaw (2007: 227). 
four of the duodecimo. Wing P2143A is identical in format and page count (58 pages) to the glossary printed with the Medicinal Dispensatory, and the website of the Antiquarian Booksellers' Association of America (http://search.abaa.org/) notes that of the extant copies of A Physical Dictionary, at least two are "extracts from a folio edition", presumably the Medicinal Dispensatory. A possible explanation is that Garfield may have started out selling prints of the glossary and then produced the duodecimo edition which, in a sense, could be considered the first and only edition specifically printed as a separate dictionary. There is no evidence of further editions of a separately bound Physical Dictionary.

With the exception of some details on the title pages, the dictionary was almost an exact copy of the glossary. This even extends to the stationer's preface and epistle, the first of which in particular seems too specific to the glossary to be included with the dictionary verbatim. While the glossary is bound between the preface and the main text in editions of the Medicinal Dispensatory printed for Garfield and Sawbridge, ${ }^{17}$ in the others it is bound after the body of the text in the others. At least in the Sawbridge edition consulted for this study, the glossary ends with what appears to be the title page for the forthcoming separate edition of the Physical Dictionary - an odd place to advertise a dictionary which the reader already has in his hands. However, it does tell us that Garfield was intending to publish the separate volume already by the time the Dispensatory was being printed. The advertisement states that the dictionary is:

Published for the more perfect understanding of Mr. Tomlinson's Translation of Rhenodaeus Dispensatory, And whatever other Books of Physick and Surgery are extant in the English tongue.

The title page eventually published with the free-standing volume is somewhat different. Although the general layout and typography of each is very similar, any mention of either Tomlinson or Renou's Medicinal Dispensatory has been erased from the title page, probably in an effort to peddle the Physical Dictionary as a wholly independent work. The stationer's preface, being identical in the glossary and the dictionary, still retains a direct reference to the Dispensatory. Given the timeline, it seems likely that the Sawbridge edition was printed somewhat later than the others, albeit still within the same year.

Next to nothing is known about John Garfield himself. He was apprenticed to Hannah Allen ${ }^{18}$ from 1649, and, when freed, set up his own company, the Rolling-Press for Pictures, near Allen's shop over against Pope's Head Alley near the Royal Exchange in Corn-hill. Pope's Head Alley (or Popes-headalley, as given on the title page) was a lively passage with several printer's shops, with the Pope's Head Tavern having been for many decades a gathering point of booksellers (see Wittich 1988: 48). Plomer (1907) gives Garfield's active years as 1656 to 1659. If we go by entries in the Stationer's Register, Garfield appears to have been fairly active during those few years, including printing several other medical titles. ${ }^{19}$ Barber notes that the titlepage of Daphnis and Chloe (1656), perhaps the best known of Garfield's books, carries one of the earliest representations of a rolling press for copperplates (1989: 22-23). The prominence of the illustration, occupying as it does half the page, suggests that the press was an object of considerable pride to Garfield, and major commercial asset.

\footnotetext{
${ }^{17}$ George Sawbridge the elder was a prominent printer and bookseller specializing in medical works. His titles also include several dictionaries, including the first and second editions of Blount's Glossographia (1656 and 1661) and the fourth (1671) to eighth (1688) revised editions of Bullokar's English Expositor. See Starnes and Noyes (1991).

18 Hannah Allen's imprint is to be found in over 60 titles in the ESTC, mostly religious in nature.

19 Other titles printed by Garfield include a translation of Daphnis and Chloe (1656), Ochinu's Dialogues of Polygamy and Divorce (1656) and The Surgeons Guid [sic] (1658). Titles entered by Garfield into the Stationers' Register which have not survived include Rulanda's Phisicall observations (Dec 16, 1656), Bread from Heaven (Jan 19, 1657), and A practicall commentary upon all the bookes of the Old Testament (Dec 20, 1657).
} 
The Physical Dictionary was printed by Gertrude Dawson, ${ }^{20}$ a friend of Hannah Allen's and the widow of John Dawson, a printer of numerous titles for Peter Cole, the stationer of the Practice of Physick; we shall examine the significance of this connection later. Gertude Dawson was a prolific printer, several medical titles aimed for female householders appearing among her editions (Furdell 2002: 109). A further tenuous connection to medicine can be traced through Livewell Chapman, another apprentice of Hannah Allen's. Chapman, who became Allen's second husband, was not only a printer of puritan literature like his wife, but a well-known Fifth Monarchist and peddler of medicines, a relatively popular sideline for booksellers (see Isaac 1998). ${ }^{21}$ This would have put Chapman in contact with apothecaries and possibly physicians, and thus provided Garfield with connections to the empiricist medical community and in particular apothecaries who, as will be mentioned, appear to figure heavily in the production of the Physical Dictionary. Chapman was a friend of Giles and Elizabeth Calvert, well known printers of seditious literature. ${ }^{22}$ Giles Calvert was one of other stationers to sell the Medicinal Dispensatory, and a business partner of John Streater, one of its two printers. Dawson printed the Chymical, Medicinal and Chyrurgical Addresses: Made to Samuel Hartlib for Calvert in 1655. This a matter of potential interest to us here because the book contains two short translations (pp. 89-99 and 101-112) of Renou's "French conferences". This not only ties both Calvert and Dawson to translations of Renou's works prior to the Medicinal Dispensatory, but also suggests that Garfield's commission to produce the glossary may have come about through Dawson.

The name of the lexicographer who compiled the dictionary is not given on the title page, nor in the prefatory material. Garfield makes it clear he did not compile the dictionary himself, but that he "caused the [difficult words in Tomlinson's translation of de Renou's Dispensatory] to be explained by able persons, well acquainted with the Practice of Physicke". Contemporary printed works eagerly advertised associations with noted individuals, and thus the anonymity of the lexicographer signals that either the lexicographer did not want his name published or he was someone whose name was deemed unfavorable for marketing purposes. Garfield's use of a plural noun, "persons", seems strange as well, since the idea that a minor stationer like Garfield would have assembled together a whole team of specialists to work on a relatively small glossary seems very unlikely. ${ }^{23}$ If one wanted to entertain such a notion, a likely set of candidates could be the fourteen physicians, surgeons, apothecaries and students who wrote the epistle, some of whom may have been involved with the lexicographical work. However, as will be seen next, the dictionary does not indicate such large scale collaboration. On the other hand, there are grounds for suggesting that the single lexicographer may well have enjoyed the benefit of a colleague's knowledge.

\section{Lexicographical description}

Turning now to the composition of the Physical Dictionary, we will do well to take as a starting point the fact that it was originally conceived as a glossary. The stationer's preface notes:

And whereas there are many Words in Mr. Tomlinson's Translation of Rænodæus Dispensatory, not understood by any ordinary Scholars (much less such as are not)

\footnotetext{
${ }^{20}$ Like most female printers and stationers, Gertrude Dawson took over the business after the death of her husband, John Dawson. Plomer (1907) notes that the Dawsons were noted for their "large and varied assortment of letters." The Dawson's titles include the 1665 edition of Robert Recorde's Urinal of Physick, the 1547 first edition of which came with one of the first glossaries in an English medical book and was noted for the author's preface advocating the teaching of medicine to medicos not learned in Latin and Greek. A 1599 edition was printed by Thomas Dawson, possibly a relation.

21 Chapman's last name is curiously fitting as the name 'chapman' was commonly used of hawkers and pedlars of various merchandise such as cheap books and pills. Raven (2007: 5) notes chapmen as one of the lowest ranks of booksellers.

22 An example of Chapman's own activities in political printing is Milton's The Ready and Easy Way to Establishing a Free Commonwealth (1660)

23 Landau notes (2001: 52) that the idea of soliciting the help of specialists was introduced to English dictionarymaking by Phillips in The New World of Words (1658).
} 
I have caused them to be explained by able persons

The Physical Dictionary includes 1705 headwords, some of which consist of two or more words, in addition to which a small table of weights and measures can be found before the dictionary proper. There are no illustrations. The headwords are arranged in alphabetical order by the first letter only; under each letter, the order of headwords is not systematic. Typically for the period, the letters I and J, and $\mathrm{U}$ and $\mathrm{V}$, are conflated, giving 22 alphabetical headings in total. The distribution of headwords is quite balanced across the dictionary, particularly considering the nature of medical terminology (see chart 1). There are no apparent signs of 'alphabet fatigue', that is, of a notably decrease toward the end of the alphabet beyond that which is to be expected on the basis of alphabetical distribution (see Osselton 2007).

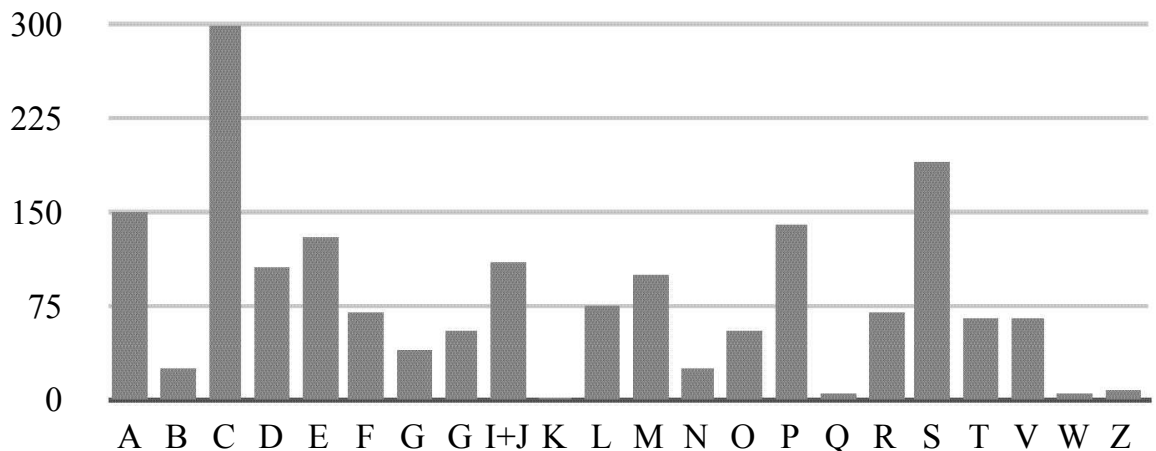

Figure 1. Headwords by letter

The headwords, which include nouns, verbs and adjectives, are primarily Latin or Greek, either in the original form or slightly anglicized. The dominance of foreign lexicon is such that the Physical Dictionary could arguably be considered a Latin-English, rather than monolingual, dictionary as suggested by Blank (2006: 235). The headwords cover the full range of topics found in contemporary medical practice, showing however a clear preference for materia medica and herbs, the one area of lexicon in which an attempt at systematic coverage appears to have been made. Reproduction and women's diseases are also well covered, perhaps reflecting in some way the influence of the many female printers and stationers associated with the dictionary. ${ }^{24}$ Vernacular words for illnesses and other medical matters are mostly absent, with the exception of a small selection with a domain-specific meaning such as "elevation", "mother" and "translation". English names of body parts are not included at all. On the other hand, a number of non-medical hard words can be found; examples include "discuss", "extension", and "similarity".

The definitions are generally concise and surprisingly consistent in style, betraying no sign of blatant copying from numerous extraneous sources. The case may be made, however, for the theory that several authorities were consulted, either in person or through reading their works. In the case of shorter definitions, several alternative translations are frequently provided, as in:

Congelation, benumning, unsuitablenesse, a freezing together with cold

Generous, brave, noble, liberal

Longer definitions occasionally offer several meanings, explicitly noting the existence of alternative opinions. For example:

Mumia, a thing like pitch sold at the Apothecaries: some affirm it's taken out of old

24 Furdell (2002: 102-104) notes that the role of women was considerable in seventeenth century medical publishing, both as patrons of medical publishing and as printers and stationers. Many appear to have had a particular affinity for empiricist causes. 
Tombs, being the embalming of dead bodies: others say it's made of mans flesh boyled in pitch: it's hot in the second degree, and good against bruisings, and spitting of bloud.

No pronunciation guidance, usage notes, or etymologies are provided, ${ }^{25}$ although very infrequently a headword is followed by a comment on the use of the same word in another language; Latin is mentioned three times. In line with the previous observations, entries for medicinal plants and minerals are again treated with greater attention, with explanations often noting the land of origin such as Egypt, Africa, and Libya. Items of materia medica also frequently come with short descriptions of use. These are notably longer than most other definitions, and support the view that the dictionary was compiled by someone with particular interest and expertise in apothecary.

Jujubes, certain Plums of Italy, sold here by Apothecaries, some of them are white, others red, round like an Olive, of a sweet taste, having a small hard stone: if they be long kept they grow dry, and full of wrinkles: they are of a temperate quality, and are good against the cough, roughness of the throat, and against all exulcerations of the kidneys and bladder; but of hard digestion.

Occasionally these longer explanations offer fascinating glimpses into the contemporary world. For example:

Mandrake, a forrein plant, bearing yellow round Apples: the root of this herb is great and white like a Parsnip, growing in two branches, like the legs of a Woman, which gives opportunity to Jugglers to Counterfeit obscene beastly Images therewith: the root, especially bark is extreme cold and dry, even to the fourth degree: it is therefore very dangerous to be taken inward: it's usually given to cast people into a dead sleep when they are to be dismembered or cut of the stone.

The condemnatory tone of the remark about jugglers' comedic use of mandrake roots is itself an interesting diversion from the generally matter-of-fact style of the entries. Moreover, the example also demonstrates the lexicographer's considerable degree of specialist knowledge in the humoral properties of medicinal plants, and makes a reference to the early practice of anesthesia.

Finally, some definitions include a cross-reference, such a "escheotics", explained as "potential cauteries: see Cauteries." Since cross-referencing was only beginning to appear in dictionaries at the time, the lexicographer once again shows a level of professional skill. On the other hand, the lexicographer does not cite scholarly works or refer to authorities, either ancient or contemporary, with two notable exceptions: the Practice of Physick and Woodall's Surgion's Mate - the latter of which is also one of the earliest lexicons to include cross-referencing.

\section{Scavenging or collaboration?}

A frequent topic in historical lexicography concerns heritage - that is, the discovering of whether, from where, and to what extent one lexicographer derived words and definitions from another. In the case of A Physical Dictionary, sources have been identified by Alston (2004) and Schäfer (1989). In this section, we shall look at these sources in detail, and discuss the ways in which each source text can be connected to the Physical Dictionary following up on the network of contemporary printers and stationers.

As noted in the introduction, Alston's comment that the Physical Dictionary was "clearly derived"

25 Considering how etymological notes were introduced into English lexicography in Blount's Glossographia in 1656, only a year before the Physical Dictionary, their absence is not in itself a curiosity. Usage guidance was also not common until the eighteenth century; see Osselton (2006) and Cormier (2008). 
from a glossary by the same name in Lazare Riviére's The Practice of Physick $(1655)^{26}$ has been refuted on the Antiquarian Booksellers Association of America website, where in the description of $A$ Physical Dictionary it is noted that "a comparison reveals that the two glossaries have nothing whatever in common." Although some similarities and even identical explanations can be found, the vast majority of both the headwords and explanations in the Physical Dictionary do not owe to the source. With 1705 headwords the Physical Dictionary is nearly three times the size of the glossary of the Practice of Physick, which has only 586. ${ }^{27}$ Consequently, even if all the headwords and definitions of the glossary had been copied - which is not the case - we would still be left with more than two thirds of the dictionary to be explained, either as original compositions or derivations from some other sources (see figure 2).

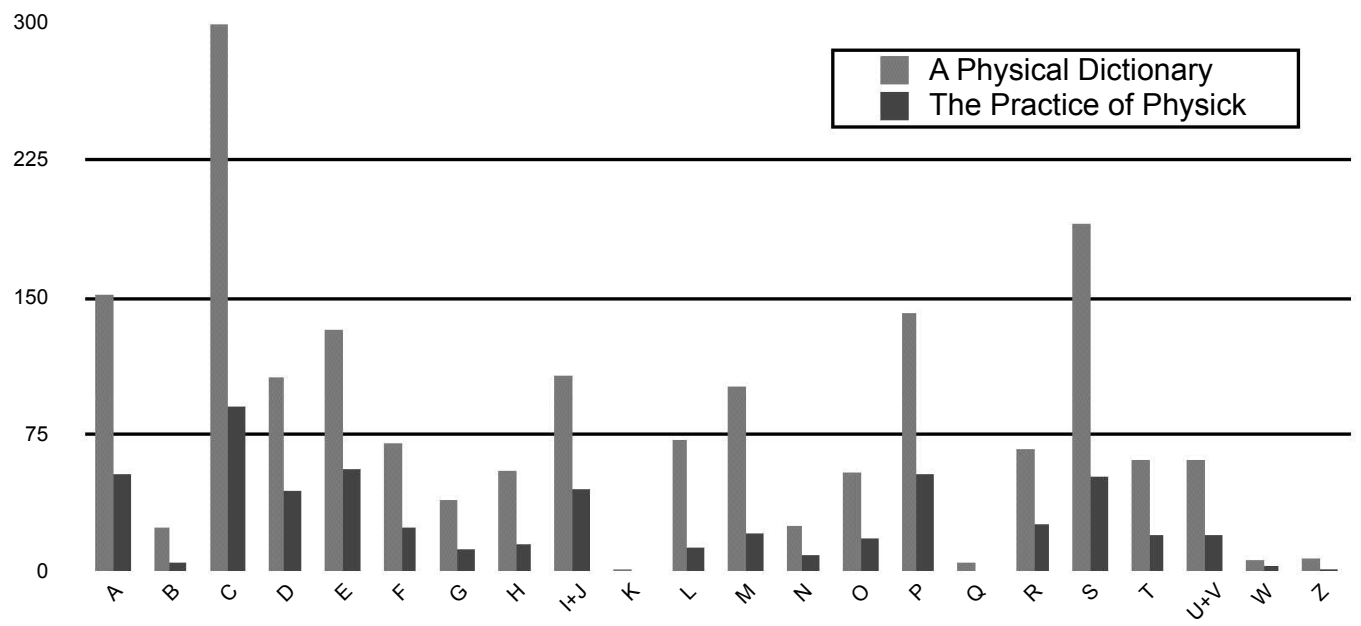

Figure 2. Number of headwords by letter in each glossary

To take the letter A as an example, we find 53 headwords in the glossary to the Practice of Physick, and 151 in the Physical Dictionary. Only 29 of the headwords in the former are found in the latter, leaving 122 or roughly 80 percent unaccounted for. Given the specialized field of the glossaries, this amount of overlap is surely to be expected. As things stand, only seven definitions out of the 29 are close enough to suggest outright copying.

However, although the Physical Dictionary was not an outright copy of the glossary in the Practice of Physick, there are certainly grounds for further examination of their relationship. Let us begin by noting that the claim made on the ABAA website that the two had "nothing whatever in common" is clearly not true. In addition to the explanations copied verbatim, many others share at least some similarities. The entry for "Aneurism", for example, is given in the Physical Dictionary as "a swelling caused by the breaking the internal coat of an Artery, the external being whole", while the Practice of Physick gives the same as "a Swelling caused by a dilation of the Arteries external Coat, the internal being broken". There can hardly be doubt that the two are the product of more than coincidence. Similarly, "medium" is given in the Physical Dictionary as "whatever is transparent, or may be seen through, is called a medium to the sight, principally the air as its either thick or thin; also glass, water, horn, are called mediums when question is of seeing through them"; the Practice of Physick gives this

26 Because of the similarities in names, Riviére's treatise has been occasionally confused by modern scholars not Alston - with the Compleat Practise of Physick (1656) by John Smith; to add to the confusion, both were produced by John Streater. The Compleat Practise of Physick is also a work of some lexicographic interest. Alphabetically arranged, it is essentially a medical encyclopedia. The novelty of the arrangement is noted in the preface.

27 By comparison, the glossary compiled by Bartholomew Traheron for de Vigo's Most excellent workes of chirurgerye (1543) a hundred years before contained 426 headwords. On the other hand, compared to the size of contemporary general dictionaries like Bullokar's English Expositour (1657) or Blount's Glossographia (1658), the Physical Dictionary's origins as a glossary are quite apparent. 
as "that through which we see, as principally the Air, which we look through upon objects; also the Water and Glass, Horn, or what ever is cleer [sic], and may be seen thorough, may be termed a medium of sight." The fact that the lexicographer opts to rearrange such relatively complex explanations instead of simply rewriting them entirely is noteworthy and asks more questions than it answers. Could the practice be taken as a sign of the same lexicographer recycling his own work, or of one copying another? In the latter case, what is to be gained by doing so? Certainly the objective cannot have been a serious case of hiding illicit copying.

A reference in the preface of the Physical Dictionary may also be read as providing additional evidence to support Alston's observation. Garfield writes, "I caused the [difficult words in Tomlinson's translation of de Renou's Dispensatory] to be explained by able persons, well acquainted with the Practice of Physicke". Although "practice of physicke" was a common enough phrase, the capitalization and distinct type leave room for speculation that reference may in fact be made to a proper name, rather than to medicine as a branch of learning. ${ }^{28}$ This theory is substantiated further by another direct reference, found in the explanation for phthisis, which reads: "a kind of consumption; see Culpeper's Practice of Physick." There is no obvious reason why a reference to another book would have been particularly necessary here, nor why Culpeper should be mentioned; after all, he was the translator, not the author, of the book in question. Although the reference could perhaps be explained simply as an exercise in salesmanship - a well-placed reference or two to a highly regarded recent title never hurt - but then would we expect the reference to be more prominent, rather than being hidden in the preface?

Perhaps the reference can be taken as a hint of the fact that whoever compiled the Physical Dictionary also had a hand in producing the glossary in the Practise of Physick, or at least that the two glossaries were closely associated with each other. Although the Practice of Physick bears several similarities to de Renou's Medicinal Dispensatory - it, too, was a translation of a French medical treatise with a glossary compiled by an anonymous author - it ended up being a considerable commercial success (Furdell 2002: 42) for the publisher Peter Cole, to whose role we shall return shortly.

The most likely connection between the two glossaries, however, must be the translators of the two books with which they were issued. Both Nicholas Culpeper, ${ }^{29}$ the translator of the Practise of Physick, and Richard Tomlinson, the translator of the Medicinal Dispensatory, were prominent apothecaries. The community of apothecaries being what is was in the 1650 's, the two men certainly would have known each other personally, and it seems quite implausible to think that each would have translated a major French medical treatise at the same time without some knowledge of each others undertaking — to say nothing of the fact that both treatises were equipped with identically entitled glossaries heavy on apothecary terminology, both by anonymous lexicographers.

Culpeper (1616-1654) was a famously controversial astro-physician and apothecary who wrote extensively on herbs and medicines. His greatest fame, or infamy, came as the translator of numerous medical treatises, most notable of which may have been the unlicensed translation of the Latin Pharmacopeia Londinendis under the title The London Dispensatory (1661). This infuriated the members of the Royal College, who considered Culpeper's activities tantamount to revealing the well guarded secrets of the profession to the non-Latinate medicos. The idea of producing a glossary would

\footnotetext{
28 'Practice of physick' is mentioned for a second time under the headword 'lac virginis', explained as "Maiden milk: see the preparation in the general practice of Physick". The preparation of 'virgin milk' is discussed on page 197 of the Medicinal Dispensatory.

${ }^{29}$ Although two other physicians, Abdiah Cole and William Rowland, also participated in the translation, Culpeper is by far the most prominent of the three, and also the one most clearly identified with pharmacopeia, the one conspicuously well-represented topic in both glossaries. Some controversy surrounds the translation of this and other works by Culpeper and Cole. In his translation of Schröder's The Compleat Chymical Dispensatory (1669), Rowland, who like Culpeper was a physician, claims to have been the true translator of all works ascribed jointly to Culpeper and Cole. Interestingly, one such title is The Golden Practice of Physicke (166?). Abdiah Cole's possible kinship to the publisher Peter Cole is not clear. See "Cole, Abdiah" in the Oxford Dictionary of National Biography by John Symons.
} 
have gone perfectly with Culpeper's personal beliefs. ${ }^{30}$

Tomlinson, on the other hand, is not known to have either translated or produced anything beside the Medicinal Dispensatory, and it seems likely that the "englishing and revising" of the Dispensatorium Medicum was a matter of some personal importance to him, rather than a mere translation job. ${ }^{31} \mathrm{He}$ became a prominent member of the Society of Apothecaries and is remembered as a generous contributor to the rebuilding of the Apothecaries Hall after the Great Fire. The fact that Tomlinson is depicted on the title page as an equal of Renou makes it clear that his role in translating the Dispensatorium included a considerable amount of revision in addition to translating. While there is no direct evidence of his involvement in the production of the glossary later published as the Physical Dictionary, it seems likely that he was.

Meanwhile, a tentative connection can also be found between Garfield and Culpeper. On June 22, 1656, Garfield entered another apothecary title, Morelius's The apothecaries shop opened, in the Stationer's Register. The title was soon after transferred to Nathaniel Brooke, a fellow stationer based in Cornhill near the Royal Exchange. Brooke published the book in 1657 under the title The Expert Doctors Dispensatory. The whole art of Physick restored in Practice. The Apothecaries Shop, and Chyrurgions Closet open'd. The translator of the treatise was claimed to be none other than Nicholas Culpeper, who professes in the preface to present the translation "to his Country-men", echoing the language of Garfield's preface. ${ }^{32}$ The rivalry between Cole and Brooke over Culpeper's works is well recorded (see Rhinelander 1996), and dealing with both puts Garfield in an interesting positions to say the least, not to mention the fact that George Sawbridge, one of the stationers of the Medicinal Dispensatory, was also a prominent seller of Culpepers' titles (Furdell 2002: 47-48) and thus another rival of Cole.

The publisher of the Practice of Physick, Peter Cole, was a controversial character best remembered as the publisher of popular medical titles, in particular those of Culpeper - many after the author's death (see Rhinelander 1996). He was a noted publisher of puritan literature which, according to Furdell (2004: 772), both made him a wealthy man and matched his personal ambitions. Cole's shop, "at the Sign of the Printing Press in Cornhill, near the Royal Exchange", was literally next door to Garfield, and his connection with the Medicinal Dispensatory can be traced through John Streater, who succeeded to Cole's copies of Culpeper's titles (see Furdell 2002: 43). ${ }^{33}$ Even some of the language in Cole's preface sounds curiously similar to Garfield's; Cole writes: "I have caused a Physical Dictionary to be added at the end of these Books, explaining all such terms of Art aforesaid, as are used therein." Although nothing more than an isolated piece of the puzzle, the unusual usage of the verb "cause", by both Garfield and Cole, strikes the ear as suspicious. As noted earlier, the first husband of Gertude Dawson, the printer of the Physical Dictionary, printed several titles for Cole, so once again at least a tentative personal connection can be established between Garfield and Cole - and thus between the two glossaries.

Although the references to the Practice of Physick in the Physical Dictionary could perhaps be read as nothing more than honest citations, they are striking in being one of only two references to contemporary authorities in the dictionary. The other, to the well-known naval surgeon and SurgeonGeneral to the East India Company John Woodall, appears in the explanation for "trafine" and reads "an

\footnotetext{
${ }^{30}$ It is worth noting that although he advanced the printing of medical information in English, Culpeper did not advocate the dissemination of medical knowledge to laymen, only to non-Latinate practitioners of medicine (see Wear 2000: 61).

${ }^{31}$ Curiously, Tomlinson is mentioned in a footnote on a point of vocabulary in the Works of William Shakespeare (1810: 47) by the editor Isaac Reed as "that prince of verbose and pedantic coxcombs." It is unclear why Reed would have characterized Tomlinson in such a way — "coxcombs" is hardly a flattering description — and whether the evaluation was based solely on the Medical Dispensatory.

32 Culpeper died in 1654, which casts some doubt on his having translated the Expert Doctors Dispensatory. Culpeper's titles were published posthumously by both Cole and Brooke, and at least some of them are known not to be from his own pen.

33 Furdell (2002: 42) notes that the premises in Cornhill were not Cole's only printing shop, and that his primary place of business was in Leadenhall. What is significant here is that Cole maintained the Cornhill shop for over twenty years, and that that property was devoted to his medical publishing.
} 
invention of our famous Chirurgion Mr. Woodall, it being an instrument by him used instead of a Trepan, and far more commodious, as you may see in his Surgeons Mate." Interestingly, one of the names on the epistle reads "Ralph Woodall, chirurgion" - almost certainly a relation of John Woodall. This is of particular interest because Woodall's Surgion's mate (1617) was also a source for the Physical Dictionary (see Schäfer 1989), reinforcing the notion that the dictionary may have been compiled using reference works to which some type of a personal connection could be established. ${ }^{34}$ The entries are likely to have come from the 1655 edition, printed by John Legate for the stationer Nicholas Bourne who, like Garfield and Cole, had his shop in Cornhill, near the Royal Exchange - giving us the third printer of medical glossaries, within two years of each other and literally within a few dozen yards from each other. Schäfer gives only a single example, "buccellatio", but a further comparison quickly reveals a systematic, if curiously sporadic pattern of copying. Five of the six lemmas under "A", as well as their definitions, were copied verbatim into the Physical Dictionary, likewise the single entry under "B". Under "C", the first 11 lemmas up to "coagulation" are all found in the Physical Dictionary, four with identical definitions. Then, all of a sudden, the copying ceases, only to pick up again later. Verbatim copies are found here and there throughout the dictionary, as well as further evidence of the practice of slight reordering of explanations. For example, 'elaboration' is given by Woodall as "a manual operation, whereby we extract from a substance the most excellent matter, the ignoble parts remoued", while the Physical Dictionary gives this as " a manual operation, an extracting of ignoble matter from that which is more excellent". Sometimes individual words are replaced by a more vernacular synonym; for example, 'illiquation' is given by Woodall as "the commistion of terrene bodies with Metalline (as of Lapis cadmia with cuprum) but so as each retains his own substance" and in A Physical Dictionary as "the mingling of earthy bodies with mettalline so as both retain their own substance". These acts of syntactical and lexical subterfuge are consistently and at times inventively executed and their distribution across the entire glossary signals the work of a single lexicographer. As noted above, Woodall's short glossary uses cross-referencing of entries, a feature which the compiler of the Physical Dictionary may have adopted from there.

The glossary in John Tanner's The hidden treasures of the art of physicke (1656), a popular medical treatise for the less learned physician, is another piece of the puzzle. Compiled by the author, it shares a number of identical definitions with both the Practice of Physick (from a year earlier) and the Physical Dictionary (published a year later). Printed by George Sawbridge - one of the stationers selling the Medicinal Dispensatory, and thus the glossary version of the A Physical Dictionary - Tanner's book falls in place with the by-now familiar pattern of stationers and printers connecting medical glossaries.

Finally, Schäfer (1989) cites both Bullokar's English expositour (1616) and Cockeram's The English dictionarie (1623) as sources for the Physical Dictionary, giving Cockeram (1623) as the source of "concinnated". As discussed by Noyes (1939) at some length, Cockeram copied Bullokar quite systematically, and it appears that the items that appear in the Physical Dictionary are primarily those shared by Bullokar and Cockeram. The first three editions of Bullokar's English expositor, published in 1616, 1621, and 1641, were identical. However, subsequent editions were "significantly enlarged" (Schäfer 1989: 60). Two of the later editions came out just before the Physical Dictionary, in 1654 and $1656 .{ }^{35}$ There is, however, reason to suspect that the source used was Cockeram, and by now it should not come as a surprise that a connection can be established between Garfield and Cockeram's English Dictionarie, or that once again the link is made through stationers and printers, rather than authors. The mid-century editions of Cockeram were printed by Andrew Crooke, a prominent bookseller and printer. In 1643, John Dawson, the first husband of Gertrude Dawson, printed a military manual written by William Barriffe entitled Military Discipline, or The young artillery-man for Crooke.

All in all, the evidence points to a combination of collaboration and copying of medical glossaries and contemporary dictionaries. To give an example, $10 \%$ of the definitions of the 257 headwords under

\footnotetext{
34 With editions printed in 1617, 1619, 1639 and 1655, Woodall's surgical guidebook was one of the major reference works on surgical technique for more than half a century.

35 Schäfer gives the explanation of "acacia" as an example of a copied entry. Although true - the relatively lengthy definition is copied almost verbatim - Schäfer's choice of example is not devoid of irony: exactly the same definition can also be found in Traheron's glossary to de Vigo's Most excellent works of chirurgery (1543), antedating Woodall's entry by nearly 70 years. It appears Woodall was not above copying choice entries either.
} 
"C" are direct copies from the Practice of Physick, 4\% from Woodall, 2\% from Cockeram, and 4\% from Tanner (see figure 3). Although the total number of copied explanations amounts to only $22 \%$, it can be taken as tentative evidence that more than occasional derivation took place.

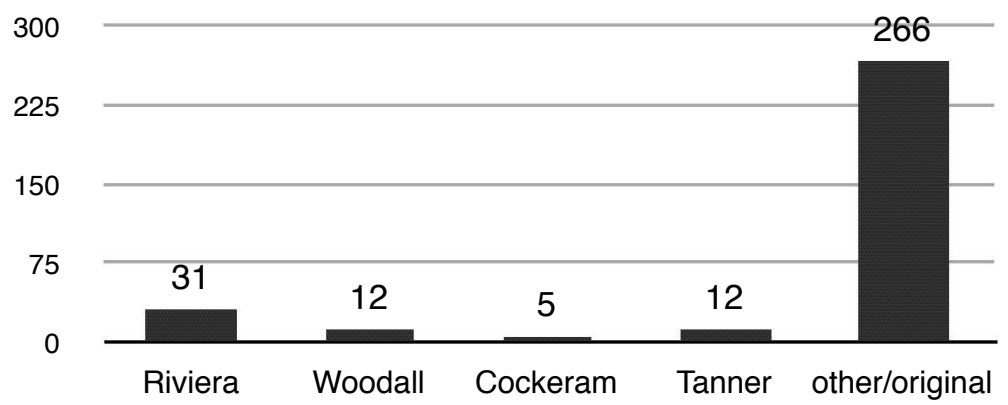

Figure 3. Sources of headwords under "C"

More interesting, however, are the connections between the Physical Dictionary and the earlier glossaries. At least five earlier lexicons were used as sources: Riviere's The Practice of Physick, Woodall's Surgion's Mate, Bullokar's English expositour, Cockeram's English dictionarie, and Tanner's The hidden treasures of the art of physicke. Although the use of source material does not dispute Garfield's claim to have consulted knowledgeable experts - for experts certainly do consult earlier works - it does cast considerable doubt on the good stationer's account of the events, unless the consultation took the form of reading their works and copying relevant entries. On the whole, this seems unlikely, particularly in light of the level of pharmacological expertise required, although admittedly in the case of Woodall's glossary, in particular, the copying appears to have been systematic.

It it much more plausible that one of two scenarios transpired, and this is where we must move from fact to hypothesis, at least for now. After taking on the task of producing a glossary for the Medicinal Dispensatory, Garfield either wrote it himself, copying all the entries from glossaries and dictionaries available to him, or commissioned them from an expert. If the former is the case, it seems inevitable that all the definitions must be copies. On the basis of evidence collected so far, this seems unlikely, even if the fact that the source texts we have identified appear to have been printed in close proximity to Garfield's shop would support the notion that either Garfield himself, or someone closely connected to him, produced the glossary relying on reference works produced by fellow printers and stationers. ${ }^{36}$ This observation is potentially of interest, particularly in view of how the preponderance of scholarship on historical lexicography tends to focus on the lexicographers themselves, rather than the circumstances in which the works were produced and published.

However, it may also be argued that the explanations in the dictionary, brief as they are, are too scholarly to have been written by someone with no medical expertise. Even the task of selecting the headwords would have required reading the thick medical treatise and knowing which words to select for the glossary in the first place. There is nothing in the slight information we have on Garfield to suggest that he would have been capable of this. In this light, the translator Richard Tomlinson must be considered the man most likely to have been the lexicographer. If we accept this hypothesis, and further that Nicholas Culpeper compiled the glossary in the Practice of Physick, the weight of circumstantial evidence gives rise to the suggestion that the two apothecaries may have either worked together, or at least that Tomlinson, clearly the less experienced writer, used Culpeper's work as a guideline when writing his glossary. Much more interesting than the occasional copying of explanations verbatim is the overall stylistic similarity, which suggests that although the majority of entries in the Physical Dictionary do not owe directly to the earlier glossary, an intriguing relationship nevertheless existed

\footnotetext{
${ }^{36}$ Naturally, the relatively small number of printers working in London in the mid seventeenth century of course means that associations are bound to come up in detailed examination of any network of books. Raven (2007: 47) gives the figure of between 40 and 59 printing houses and perhaps the same number of presses in London in the 1650s.
} 
between the two. Further research is clearly needed.

\section{Some remarks to conclude with}

It is always difficult to gauge the contemporary reception of early printed works, and in the case of a obscure work like the Physical Dictionary any attempt to do so can only be tentative. Judging by the almost non-existent references to the dictionary by contemporaries and later scholars alike, it would certainly appear that the Physical Dictionary never made an impact. With the exception of William Cooper's Catalogue of Chymical Works (1673), ${ }^{37}$ which ascribes the authorship of the Physical Dictionary to "Anonymous", subsequent Early Modern medical dictionaries and medical texts appear to ignore it entirely. The prefatory texts of neither Blankaart's Physical Dictionary $(1684)^{38}$ or any of the subsequent medical dictionaries mention A Physical Dictionary. Importantly, the evidence shows that the lack of longevity and historical significance must not be understood in any way as a reflection of the dictionary's lexicographical merit, but that in contrast the Physical Dictionary is an original and professionally compiled reference work.

Secondly, and more significantly still, the brief examination presented here suggests that when it comes to explaining the choices made by early lexicographers, circumstances of production may be of much greater significance than is often allowed for in modern scholarship, which frequently favours the view that even early lexicography was something akin to an academic pursuit and that dictionaries were products of an essentially scholarly enterprise. While there is certainly nothing revolutionary in this conclusion, it seems that perhaps more attention ought to be paid to the business of publishing, rather than the more lofty intellectual objectives. Consequently, it may be that charges of scavenging and outright theft are often far too easily leveled at early lexicographers, when in reality there may have been collaborative arrangements arising out of yet-to-be uncovered personal and business relations.

\section{References}

\section{Primary references (short titles)}

Anon. 1657. A Physical Dictionary. Printed by G.D. for John Garfield and are to be sold at his Shop at the Signe of the Rolling-Press for Pictures near the Royal Exchange in Corn-hil, over against Popes-head-alley. London.

Blankaart, Stephen. 1684. Physical Dictionary. Printed by J.D. and are to be sold by Samuel Crouch in Pope's Head Alley, and John Gellibrand at the Golden-Ball in St. Paul's Churchyard. London.

Blount, Thomas. 1656. Glossographia. By T.B. of the Inner Temple, barrister. London.

Brugis, Thomas 1640. Marrowe of Physicke. Printed by Richard Hearne. London.

Bullokar, William. 1656. English expositour. Printed by J.L. and are to be sold by Simor Waterson, at the Sign of the Globe in Pauls Church yard. London.

Cooper, William. 1657. Catalogue of Chymical Works. Collected by Will. Cooper, bookseller, at the Pelican in Little Britain. London.

Castellus, Bartholomaeus. 1598. Lexicon Medicum Graeco-Latinum. Sumptibus Arnoldi Leers. Rotterdam.

Cockeram, Henry. 1623. English dictionarie. Printed by Nathaniel Butter and to be sold at his shop at St. Austins Gate, at the signe of the Pide Bull. London.

de Renou, Jean. 1657. Medicinal Dispensatory. Printed by Jo: Cotrell and Ja: Streater; and are to be sold by George Sawbridge, at the Bible on Ludgate Hill. London.

\footnotetext{
37 William Cooper was an apothecary and bookseller who took it upon himself to compile a list of all works on chemistry. See Debus (2002: 449).

38 Blankaart's Physical Dictionary (1684) was a translation of his earlier Latin medical dictionary Lexicon Medicum Graeco Latinum. A direct reference to A Physical Dictionary would have been very unlikely by Blankaart himself, as the Dutch professor of physick could not reasonably be expected to have been aware of the Physical Dictionary. However, a point of interest to be explored in an article in preparation concerns the connection between Garfield and Samuel Crouch, one of the two stationers selling Blankaart's dictionary (the other being John Gellibrand). Like Garfield, Crouch had his shop on Pope-Head Alley, specialized in medical titles, and sold pills and other medicaments like Livewell Chapman, a fellow apprentice of Hannah Allen's.
} 
de Vigo, Ioannes. 1543. The most excellent works of chirurgery. Imprynted by Edwarde Whytchruch, wyth the kynges most gratious privelege for seven years. London.

Hartlib, Samuel. 1655. Chymical, Medicinal and Chyrurgical Addresses: Made to Samuel Hartlib. Printed by G. Dawson for Giles Calvert at the Black-Spread Eagle at the west end of Pauls.

Phillips, Edward. 1658. The New World of Words. Printed by E. Tyler for Nathaniel Brooke at the Sign of the Angel in Cornhill. London.

Recorde, Robert. 1547. The Urinal of Physick. Imprinted at London: By Reynolde Wolfe. London.

Recorde, Robert. 1665. The Urinal of Physick. Printed by G. D. London.

Reed, Isaac (ed.). 1810. The Works of William Shakespeare in nine volumes. Volume II. Printed by Munroe, Francis and Parker for themselves, Boston; Ezra Sargeant, New York; and Hopkins and Earle, Philadelphia.

Riviere, Lazare. 1655. Practice of Physick. Printed by Peter Cole in Leaden Hill, and are to be sold at his Shop, the Sign of the Printing Press in Cornhill, near the Royal Exchange. London.

Smith, John. 1656. Compleat Practise of Physick. Printed by J. Streater for Simon Miller at the Star in St. Pauls churchyard. London.

Tanner, John. 1656. The hidden treasures of the art of physicke. Printed for George Sawbridge, at the sign of the Bible at Ludgate Hill. London.

Woodall, John. 1617. Surgion's Mate. Printed by Edward Griffin for Robert Lisle at the Tyger's head in Pauls Church-yard. London.

\section{Secondary references}

Alston, Robin. 2004. A Bibliography of the English Language from the Invention of Printing to the Year 1800. Volume XVIII, Part 1. Otley: Smith Settle.

Altick, Richard. 2006 (1957). The English common reader: From Caxton to the Eighteenth Century. In Finkelstein, David and Alistair McLeery (eds.) The Book History Reader. Second Revised Edition. London and New York: Routledge. 440-449.

Barber, Giles. 1989. Daphnis and Chloe. The markets and metamorphoses of an unknown bestseller. (The Panizzi Lectures). London: The British Library.

Blagden, Cyprian. 1960. The Stationers' Company: A History, 1403-1959. London: George Allen and Unwin.

Blank, Paula. 2006. The Babel of Renaissance English. In Mugglestone Lynda (ed.) The Oxford History of English. Oxford: Oxford University Press. 212-240.

British Book Trade Index, The. 1983-. Available at <http://www.bbti.bham.ac.uk/>, accessed 16 December 2008.

Cormier, Monique C. 2008. Usage Labels in The Royal Dictionary (1699) by Abel Boyer. In International Journal of Lexicography, June 2008. 153-171.

Debus, Allen G. 2002. The Chemical Philosophy: Paracelsian Science and Medicine in the Sixteenth and Seventeenth Centuries. New York: Courier Dover Publications.

English Short-Title Catalogue (1473-1800). Last updated 10-24-2007. Available at $<$ http://estc.bl.uk/F/?func=file\&file_name=login-bl-list $>$, accessed 12 December 2008.

Feather, John. 1988. The History of British Publishing. London: Croom Helm.

Finkelstein, David and Alistair McCleery. 2005. An Introduction to Book History. London and New York: Routledge.

French, Roger. 2003. Medicine Before Science: The rational and learned doctor from the Middle-Ages to the Renaissance. Cambridge: Cambridge University Press.

Furdell, Elizabeth Lane. 2002. Publishing and Medicine in Early Modern England. Rochester: University of Rochester Press.

Furdell, Elizabeth Lane. 2004. 'Reported to be Distracted': The Suicide of Puritan Entrepreneur Peter Cole. In The Historian 66/4. 772-792.

Grafton, Anthony. 1992. New Worlds, Ancient Texts: The Power of Tradition and the Shock of Discovery. Cambridge, Mass.: Harvard University Press.

Hessayon, A. 2007. Incendiary texts: book burning in England, c.1640 - c.1660. In Cromohs, 12: 1-25. Available at $<$ http://www.cromohs.unifi.it/12_2007/hessayon_incendtexts.html>, accessed 15 April 2008.

Isaac, Peter. 1998. Pills and Print. In Myers, Robin and Michael Harris (eds.) Medicine, Mortality and the Book Trade. London: Oak Knoll Press. 25-49.

Johns, Adrian. 1998. The Nature of the Book: Print and Knowledge in the Making. Chicago: University of Chicago 
Press.

Johns, Adrian. 2002. Science and the Book. In Barnard John, D.F. McKenzie and Maureen Bell (eds.) The Cambridge History of the Book in Britain. Volume IV: 1557-1695. Cambridge: Cambridge University Press. 274-304.

Landau, Sidney I. 2001. Dictionaries: The Art and Craft of Lexicography. $2^{\text {nd }}$ Edition. Cambridge: Cambridge University Press.

Mandelbrote, Giles. 2003. Workplaces and Living Spaces: London book trade inventories of the late seventeenth century. In Myers Robin, Michael Harris and Giles Mandelbrote (eds.) The London Book Trade: Topographies of Print in the Metropolis from the Sixteenth Century. London: Oak Knoll Press. 21-49.

Menzies, Walter. 1931. Alexander Read: Physician and Surgeon 1580-1641. In The Library, s4-XII(1). 46-74.

McConchie, R.W. 1997. Lexicography and Physicke. Oxford: Clarendon Press.

McConchie, R.W. 2002. Doctors and Dictionaries in sixteenth-century England. In Jacek Fisiak (ed.) Studies in English Historical Linguistics and Philology: A Festschrift for Akio Oizumi. (Studies in English Medieval Language and Literature.) Frankfurt am Main: Peter Lang. 267-292.

Norri, Juhani. 2004. Entrances and exits in English medical vocabulary, 1400-1550. In Taavitsainen, Irma and Päivi Pahta (eds.) Medical and Scientific Writing in Late Medieval English. Cambridge: Cambridge University Press. 100-144.

Noyes, Gertrude E. 1939. Some Interrelations of English Dictionaries of the Seventeenth Century. In $P M L A$, vol 54, no 4. 990-1006.

Osselton, N. E. 1998. English Specialized Lexicography in the Late Middle Ages and in the Renaissance. In Hoffman Lothar et al (eds.) Fachsprachen: Languages for Special Purposes. Vol. II. Berlin: de Gruyter. 24582465.

Osselton, Noel E. 2006. Usage Guidance in Early Dictionaries of English. In International Journal of Lexicography, vol 19, no 1. 99-105.

Osselton, Noel E. 2007. Alphabet Fatigue and Compiling Consistency in Early English Dictionaries. In Considine, John P. and Giovanni Iamartino (eds.) Words and dictionaries from the British Isles in historical perspective. Newcastle-upon-Tyne: Cambridge Scholars Publishing. 81-91.

Oxford English Dictionary. 2003-. Second Edition, online. Available at http://www.oed.com/.

Plomer, Henry R. 1907. A Dictionary of the Booksellers and Printers Who were at Work in England, Scotland and Ireland from 1641 to 1667. London: Blades, East, and Blades.

Porter, Roy. 1992. The patient in England, c. 1660-c. 1800. In Andrew Wear (ed.) Medicine in Society: Historical Essays. Cambridge: Cambridge University Press. 91-119.

Raven, James. 2007. The Business of Books: Booksellers and The English Book Trade. New Haven: Yale University Press.

Rhinelander McCarl, Mary. 1996. Publishing the Works of Nicholas Culpeper, Astrological Herbalist and Translator of Latin Medical Works in Seventeenth-Century London. In Canadian Bulletin of Medical History / Bulletin canadien d'histoire de la médecine, 13 (2). 225-276.

Rivington, Charles A. 1984. Early Printers to the Royal Society 1663-1708. In Notes and Records of the Royal Society of London, Vol. 39, No. 1 (Sep., 1984). 1-27.

Salmon, Vivian. 1979. The Study of Language in Seventeenth-Century England. Amsterdam: John Benjamins.

Schaeder, Burkhard. 1994. Wörterbücher der Medizin — Versuch einer Typologie. In Dressler, Stephan and Burkhard Schaeder (eds.) Wörterbücher der Medizin. (Lexicographica 55). Tübingen: Max Niemeyer Verlag. 25-54.

Schäfer, Jürgen. 1989. Early Modern English Lexicography. Volume I. A Survey of Monolingual Printed Glossaries and Dictionaries 1475-1640. Oxford: Clarendon Press.

Shaw, David J. 2007. The Book Trade Comes of Age: The Sixteenth Century. In Eliot Simon and Jonathan Rose (eds.) A Companion to the History of the Book. Malden: Blackwell 220-232.

Siraisi, Nancy G. 1990. Medieval and Early Renaissance Medicine: An Introduction to Knowledge and Practice. Chicago and London: University of Chicago Press.

Starnes, De Witt T. and Gertrude E. Noyes. 1991. The English Dictionary from Cawdrey to Johnson 1604-1755. Amsterdam and New York: John Benjamins.

Transcript of the Register of the Worshipful Company of Stationers; from 1640-1708 A.D. 1913 Volume II. London: Privately printed.

Trease, George Edward. 1964. Pharmacy in History. Baillière, Tindall and Cox: London. 
Wear, Andrew. 1996. Religious belief and medicine in Earlu Modern England. In Marland Hilary and Margaret Pelling (eds.) The Task of Healing: Medicine, Religion, and Gender in England and the Netherlands, 14501800. Rotterdam: Erasmus. 146.

Wear, Andrew. 2000. Knowledge and Practice in Medicine, 1550-1680. Cambridge: Cambridge University Press. Wittich, John. 1988. Catholic London. Gracewing Publishing: London.

Webster, Charles. 1975. The Great Instauration: Science, Medicine and Reform, 1626-1660. New York: Holmes and Meier. 


\title{
Selected Proceedings of the 2008 Symposium on New Approaches in English Historical Lexis (HEL-LEX 2)
}

\author{
edited by R.W. McConchie, \\ Alpo Honkapohja, and Jukka Tyrkkö
}

Cascadilla Proceedings Project Somerville, MA 2009

\section{Copyright information}

Selected Proceedings of the 2008 Symposium on New Approaches in English Historical Lexis (HEL-LEX 2) (C) 2009 Cascadilla Proceedings Project, Somerville, MA. All rights reserved

ISBN 978-1-57473-430-0 library binding

A copyright notice for each paper is located at the bottom of the first page of the paper.

Reprints for course packs can be authorized by Cascadilla Proceedings Project.

\section{Ordering information}

Orders for the library binding edition are handled by Cascadilla Press.

To place an order, go to www.lingref.com or contact:

Cascadilla Press, P.O. Box 440355, Somerville, MA 02144, USA

phone: 1-617-776-2370, fax: 1-617-776-2271, e-mail: sales@ cascadilla.com

\section{Web access and citation information}

This entire proceedings can also be viewed on the web at www.lingref.com. Each paper has a unique document \# which can be added to citations to facilitate access. The document \# should not replace the full citation.

This paper can be cited as:

Tyrkkö, Jukka. 2009. A Physical Dictionary (1657): The First English Medical Dictionary. In Selected Proceedings of the 2008 Symposium on New Approaches in English Historical Lexis (HEL-LEX 2), ed. R. W. McConchie, Alpo Honkapohja, and Jukka Tyrkkö, 171-187. Somerville, MA: Cascadilla Proceedings Project.

or:

Tyrkkö, Jukka. 2009. A Physical Dictionary (1657): The First English Medical Dictionary. In Selected Proceedings of the 2008 Symposium on New Approaches in English Historical Lexis (HEL-LEX 2), ed. R. W. McConchie, Alpo Honkapohja, and Jukka Tyrkkö, 171-187. Somerville, MA: Cascadilla Proceedings Project. www.lingref.com, document \#2175. 